\title{
The Research and Analysis of Rural Information Poverty in Guizhou
}

\author{
He Jun, Li Ou, Cai Mei \\ The development strategy research center of Karst region \\ Library of Guizhou University \\ Guiyang, China
}

\begin{abstract}
The information poverty in Guizhou has its own character and genesis. With the rapid development of information technology, the problem is increasingly outstanding. Information poverty increases the cost of the rural economy development in corresponding areas, while hampering the economic development. In-depth and systematic research of rural information poverty in Guizhou has important value and significance. This article summarizes its characteristic, analyzes its genesis and the difficulty of information poverty alleviation work as well as explores the solutions through analysis of investigation about the present situation of information poverty in Guizhou.
\end{abstract}

Keywords-Rural Guizhou; Information Poverty; Present Situation; Genesis; Solution

\section{INTRODUCTION}

Information poverty is a new kind of poor phenomenon of information era, which is due to the strong permeability of information technology and the "digital gap" made by the extensive usage of information. In the process of informatization, regional economic development level is uneven. It leads to different regional level in information technology development and application, information processing and information infrastructure on the popularity of the gap[1] . Rural information poverty means: compared with urban area, the level of rural informatization is relatively backward in relation to infrastructure and economy. Farmers are unable to access to enough information. The obtained information is far below the amount of the demand. This is why the phenomenon of "information anemia and jams" as well as the inefficient information usage occurs.

Information poverty plays a vital role in regional development of economy. Thus, the study of its causes and countermeasures absorb the wide attention of scholars both at home and abroad. Through document retrieval of Chinese howNet, from 2000-2013, there are 21 domestic articles for the subject of "rural information poverty". These articles respectively study the causes and countermeasures of information poverty in various areas of our country, in relation to rural information supply, farmers' purchasing power, farmers' information quality and construction of rural information platform and so on. Many developing countries study information poverty in remote mountain areas as well, such as Bangladesh, Sri Lanka, and the Philippines.

Project name: Study of the information poverty in Guizhou (2013 Humanities and social science research base project in colleges and universities of Guizhou province JD2013049)
Bangladesh gonokendra model studies the information and communication technologies (ICT) in the development and improvement of extended architecture in the suffering area of the developing country. Sri Lanka's kothmale model proposes to create the appropriate model, for those who cannot access the Internet or no language ability to understand the Internet content. International edge area reconstruction agency in the Philippines (IIRR) is committed to using its own information resources, technology providers' advice and the sane decisions of the proposal to deal with the needs of the rural areas[10-12].

Guizhou is a poor province with unbalanced social and economic development. Its unique natural conditions not only affect the region's economic development, but also affect its information development. The rural information poverty problem in Guizhou is increasingly prominent. Information poverty increases the cost of the economic development in Guizhou, so to some extent, restricts the economic development. In-depth and systematic research of rural information poverty in Guizhou has important value and significance. This article summarizes its characteristic, analyzes its genesis and the difficulty of information poverty alleviation work as well as explores the solutions through analysis of investigation about the present situation of information poverty in Guizhou.

\section{ANALYSIS OF GUIZHOU INFORMATION POVERTY}

To understand current situation of information poverty in Guizhou, we collected relative statistic data of 11 provinces in the western China in 2013(see table I ). From the Internet situation, three aspects were selected to analyze the situation and degree of Guizhou information poverty. They included main user status of rural informatization, rural family information infrastructure conditions and farmers' information quality. The 11 provinces are located in the west of our country. Their economic development level is relatively backward.

\section{A. The maturity of Internet and Internet resources in Guizhou}

Liu (2012) established an Internet Maturity model in order to analyze internet maturity in 31 provinces and cities of our country through the. The result showed, if the Internet maturity from low to high can be divided into initial stage: the repeatable level, the defined level, management level and the optimizing level. 31 provinces and cities in China have been across the Internet first and second stage of maturity model. 
Beijing, Shanghai, Guangdong, Jiangsu, Zhejiang, Fujian and Tianjin have entered the management level. In the rest 24 provinces and cities, 23of them have enter the third stage except Guizhou[2]. Its Internet environment index failed to achieve the defined key process areas, and not to enter the third stage. This indicates that Guizhou has the lowest level of Internet maturity in China.

From the point of Internet resources, IPv4 addresses, domain name, web site holding quantity these three indicators, Guizhou province is in the sixth and sixth and seventh respectively among western provinces in China, stays in the middle and lower levels. In relation to the number of rural broadband user number, which can reflect the rural informatization implementation effect, guizhou is in the seventh also in middle and lower level.

TABLE I. THE NET INCOME PER PERSON IN WESTERN PROVINCES AND INTERNET RESOURCES IN 2013

\begin{tabular}{|c|c|c|c|c|c|c|c|c|c|}
\hline \multirow{2}{*}{ Province } & \multirow{2}{*}{$\begin{array}{c}\text { Per capita } \\
\text { net income } \\
\text { of rural } \\
\text { households } \\
\text { (yuan) }\end{array}$} & \multicolumn{2}{|c|}{$\begin{array}{l}\text { IPv4 addresses } \\
\text { (ten thousand) }\end{array}$} & \multicolumn{2}{|c|}{$\begin{array}{l}\text { Domain Name } \\
\text { (ten thousand) }\end{array}$} & \multicolumn{2}{|c|}{$\begin{array}{l}\text { Site holding quantity } \\
\text { (ten thousand) }\end{array}$} & \multicolumn{2}{|c|}{$\begin{array}{l}\text { Rural broadband User } \\
\text { (ten thousand) }\end{array}$} \\
\hline & & Quantity & Ranking & Quantity & Ranking & Quantity & Ranking & Quantity & Ranking \\
\hline Sichuan & 7895 & 795.6 & 1 & 34 & 1 & 11 & 1 & 188.7 & 1 \\
\hline Xinjiang & 7296 & 193 & 6 & 4.1 & 7 & 0.8 & 7 & 54.4 & 5 \\
\hline Shanxi & 7154 & 467.5 & 2 & 8.2 & 5 & 3.5 & 3 & 51.1 & 6 \\
\hline Ningxia & 6931 & 72.2 & 9 & 1.6 & 9 & 0.4 & 9 & 7.7 & 9 \\
\hline Guangxi & 6791 & 345 & 4 & 9.2 & 3 & 2.5 & 4 & 102.6 & 2 \\
\hline Xizang & 6578 & 37.8 & 11 & 0.5 & 11 & 0.1 & 11 & 0 & 11 \\
\hline Shanxi & 6503 & 347.3 & 3 & 13.2 & 2 & 3.7 & 2 & 96.4 & 3 \\
\hline Qinghai & 6196 & 55.4 & 10 & 1.1 & 10 & 0.2 & 10 & 3.7 & 10 \\
\hline Yunnan & 6141 & 313 & 5 & 8.4 & 4 & 1.4 & 5 & 76.9 & 4 \\
\hline Guizhou & 5434 & 169.3 & 7 & 4.3 & 6 & 1.0 & 6 & 44.5 & 7 \\
\hline Gansu & 5108 & 158.6 & 8 & 2.9 & 8 & 0.7 & 8 & 34 & 8 \\
\hline
\end{tabular}

${ }^{\text {a. }}$ Resource: 〈Statistical yearbook of China 2013》 , 《2013 China's Internet development report $\rangle$

TABLE II. WESTERN RURAL HOUSEHOLD LABOR CULTURE CONDITIONS (AVERAGE PER HUNDRED WORKFORCES) IN 2012

\begin{tabular}{|c|c|c|c|c|c|c|c|c|}
\hline \multirow[t]{2}{*}{ Province } & \multirow[t]{2}{*}{$\begin{array}{c}\text { Can't read or } \\
\text { read few(person) }\end{array}$} & \multirow[t]{2}{*}{$\begin{array}{r}\text { Primary } \\
\text { school }\end{array}$} & \multirow[t]{2}{*}{$\begin{array}{r}\text { Middle } \\
\text { school }\end{array}$} & \multicolumn{2}{|c|}{$\begin{array}{l}\text { Junior high school } \\
\text { and below total }\end{array}$} & \multirow{2}{*}{$\begin{array}{c}\text { Senior high } \\
\text { school }\end{array}$} & \multirow{2}{*}{$\begin{array}{c}\text { Technical } \\
\text { secondary } \\
\text { school } \\
\text { degree }\end{array}$} & \multirow{2}{*}{$\begin{array}{c}\text { College } \\
\text { graduate or } \\
\text { college degre } \\
\text { or above }\end{array}$} \\
\hline & & & & $\%$ & Ranking & & & \\
\hline Sichuan & 7.7 & 33.8 & 48.7 & 90.2 & 5 & 6.6 & 1.9 & 1.3 \\
\hline Xinjiang & 2.4 & 29.8 & 56.9 & 89.1 & 6 & 6 & 2.6 & 2.3 \\
\hline Shanxi & 3.1 & 21 & 57.1 & 81.2 & 11 & 11.9 & 3.4 & 3.5 \\
\hline Ningxia & 14.2 & 32.2 & 42.4 & 88.8 & 7 & 7.3 & 1.8 & 2.1 \\
\hline \begin{tabular}{|l|} 
Guangxi \\
\end{tabular} & 2.8 & 25 & 57.2 & 85.0 & 8 & 9.9 & 3 & 2.1 \\
\hline \begin{tabular}{|l|} 
Xizang \\
\end{tabular} & 36 & 56.8 & 6.1 & 98.9 & 1 & 0.7 & 0.3 & \\
\hline \begin{tabular}{|l|} 
Shanxi \\
\end{tabular} & 6.1 & 21.7 & 54.6 & 82.4 & 9 & 10.8 & 3 & 3.8 \\
\hline Qinghai & 18.3 & 43.9 & 28.4 & 90.6 & 4 & 5.6 & 1.5 & 2.3 \\
\hline Yunnan & 8.8 & 41.2 & 40.7 & 90.7 & 3 & 6 & 2 & 1.3 \\
\hline Guizhou & 10.4 & 38.1 & 43.7 & 92.2 & 2 & 4.3 & 2 & 1.6 \\
\hline Gansu & 10.7 & 26.8 & 45.6 & 83.1 & 10 & 11.3 & 2.9 & 2.8 \\
\hline
\end{tabular}

${ }^{b}$ Resource: 〈Statistical yearbook of China 2012》

\section{B. Rural informationization environment}

Farmers are the main body of rural informationization. Per capita net income and educational level are important indexes to measure the main body of rural informatization environment. From table I, Guizhou rural family per capita net income in
2013 is 5434 yuan, which is only higher than that of Gansu in the western provinces and ranks the second from bottom in the nation. In 2012, the annual average expenditure of rural households in Guizhou is 6372 yuan; living consumption expenditure is 3901 yuan and traffic communication cost is just 317.35 yuan $^{(1)}$. Farmers' information consumption is mainly composed of three parts, one is to buy mobile phones, TV, computer and information equipment, the second is to pay phone bill, communication expenses such as Internet access, third is to buy professional information services. At present in Guizhou, including mobile and telecom charging standard, voice calls, text messages and traffic cost, the average consumption is around 100 yuan per month. Cable TV fee is 17 yuan per month (Guizhou rural users). Apparently, the demand of purchasing information service is difficult to achieve depending on 317.35 yuan (per year per person) of traffic communication expense to acquire information infrastructure and to pay the cost of communication and information consumption ability.

Table II shows that, Junior middle school under the cultural level of rural residents in Guizhou is occupied $92.2 \%$, just above the Tibet, which is located in the penultimate of western provinces in 2012.

\section{Rural family information infrastructure}

From statistics in 2012 (tableIII),In 11 provinces in the west Guizhou ranks the second place from the bottom in relation to rural households per hundred computer holding quantity and fixed telephone holding quantity. In associate to the mobile phone holding quantity, Guizhou ranks third from bottom and has the least TV holding quantity. Rural family information infrastructure situation is not optimistic.

TABLE III. THE INFORMATION INFRASTRUCTURE HOLDING QUANTITY OF RURAL FAMILY IN 2012

\begin{tabular}{|c|c|c|c|c|c|c|c|c|}
\hline \multirow{2}{*}{ Province } & \multicolumn{2}{|c|}{$\begin{array}{l}\text { Computer } \\
\text { (hundred households) }\end{array}$} & \multicolumn{2}{|c|}{$\begin{array}{l}\text { Telephone } \\
\text { (hundredhouseholds) }\end{array}$} & \multicolumn{2}{|c|}{$\begin{array}{l}\text { Mobile phone } \\
\text { (hundred households) }\end{array}$} & \multicolumn{2}{|c|}{$\begin{array}{l}\text { TV } \\
\text { (hundredhouseholds) }\end{array}$} \\
\hline & $\begin{array}{l}\text { Holding } \\
\text { quantity }\end{array}$ & Ranking & $\begin{array}{l}\text { Holding } \\
\text { quantity }\end{array}$ & Ranking & $\begin{array}{l}\text { Holding } \\
\text { quantity }\end{array}$ & Ranking & $\begin{array}{l}\text { Holding } \\
\text { quantity }\end{array}$ & Ranking \\
\hline Sichuan & 10.0 & 8 & 32.4 & 5 & 178.0 & 8 & 108.9 & 5 \\
\hline Xinjiang & 12.5 & 4 & 29.9 & 7 & 147.3 & 10 & 101.1 & 10 \\
\hline Shanxi & 27.7 & 1 & 46.9 & 3 & 186.8 & 7 & 110.4 & 4 \\
\hline Ningxia & 14.9 & 3 & 28.4 & 9 & 242.8 & 1 & 125.2 & 1 \\
\hline Guangxi & 11.7 & 5 & 30.0 & 6 & 215.5 & 4 & 111.1 & 3 \\
\hline Xizang & 0.5 & 11 & 51.1 & 1 & 132.1 & 11 & 108.1 & 6 \\
\hline Shanxi & 17.9 & 2 & 34.8 & 4 & 229.8 & 2 & 114.7 & 2 \\
\hline Qinghai & 8.8 & 7 & 48.2 & 2 & 220.7 & 3 & 107.8 & 7 \\
\hline Yunnan & 6.2 & 9 & 11.4 & 11 & 205.1 & 5 & 102.3 & 9 \\
\hline Guizhou & 4.9 & 10 & 15.4 & 10 & 173.3 & 9 & 96.2 & 11 \\
\hline Gansu & 11.4 & 6 & 29.0 & 8 & 192.7 & 6 & 107.8 & 7 \\
\hline
\end{tabular}

\section{Farmers information quality}

Farmers' information quality refers to when the farmers can realize the need of express information correctly, can find, obtain and make use of more skillful information as well as release information at the same time, in order to meet the demand of life and agricultural production [1].

In October 2013 - March 2014, we randomly selected from Shi Qian, Wuchuan, Zenggong, Xuyang, Weining and Huaxi 5 county town and 1 propylite town, a total of 391 farmer 
families as investigation object in order to research information quality status of farmers in Guizhou. The investigation result is as following.

Farmers have certain information consciousness. However, the expression and publication of their own information own information have certain difficulty.

TABLE IV. FARMERS EXISTING INFORMATION ACQUISITION WAY AND THEIR EXPECTING WAYS $(\%)$

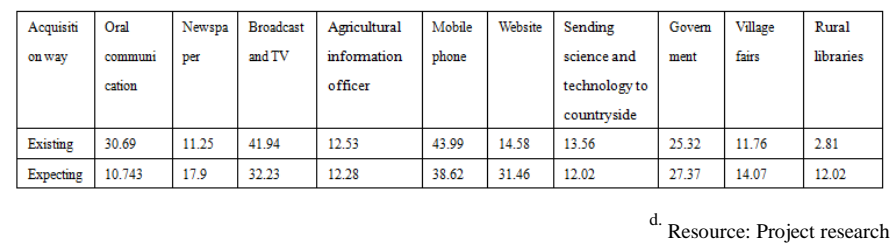

Modern means has not yet become the main means for farmers to access to information. In Guizhou, students are the main body in the netizen structure with the proportion of $32.4 \%$. The ratio of rural netizens is relatively low $(5.1 \%)$, which is lower than the national average $(6.6 \%)^{1}$. However, according to the survey, the farmers who hope to obtain information from the Internet and peasant bookstore rose to $16.88 \%$ and $16.88 \%$ respectively (Table IV), which indicates the consciousness of farmers to obtain information from modern ways have been enhanced.

Farmers have diverse information demand, but the utilization rate of all kinds of information is generally low. From the point of information demand, in the practical information, agricultural materials, information of agricultural production and rural development, the four types of information, farmers concerned agricultural information, fertilizer, higher school employment information and related policy most (Table V) . From the point of information utilization, the order of information selection frequency for farmers (from high to low) is: Government $30.95 \%$, Broadcast and TV $22.51 \%$, Mobile phones $20.97 \%$, Newspapers $14.32 \%$, Sending science and technology to countryside $13.6 \%$, Oral communication $12.8 \%$, Website $12.3 \%$, Village fairs $12 \%$ and Agricultural information officer $11.56 \%$.

TABLE V. TYPES OF FARMERS' INFORMATION DEMANDS（\%）

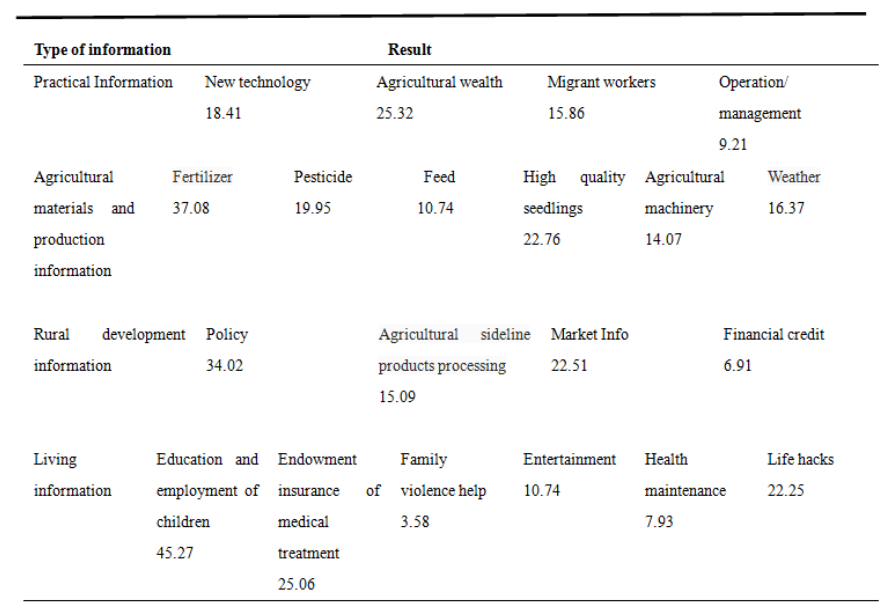

${ }^{\text {e. }}$ Resource: Project research
Based on the analysis of above, the most serious area of rural information poverty is western Guizhou. Its Internet resources have low maturity. The Internet, rural informatization subject environment is poor. Rural family information infrastructure is backward and peasants' information quality is low. Also, it belongs to the poorest area in our country in relation to rural information poverty. If there is no intervention to the phenomenon, with the rapid development of information technology, the "digital gap" will gradually deepen and information poverty in rural Guizhou will be further aggravated.

\section{THE CAUSE ANALYSIS OF RURAL INFORMATION POVERTY}

Natural conditions, economic levels and farmers' culture level, are the direct cause of rural information poverty in Guizhou. Interactions among these factors influence Guizhou rural informatization level in every aspect.

\section{A. Special natural conditions are objective causes of rural information poverty in Guizhou}

The main three geomorphic types in Guizhou are Plateau Mountain, hills and basin. $92.5 \%$ of the area is mountain and hills. The mountains account for only $7.5 \%$ of small basin. Karst area is 10.9 square kilometers, accounting for $61.9 \%$ of the province's land area. The signal transmission is mainly connected by base stations. Due to a wide distribution of karst carbonate rocks in Guizhou, the surface layers are broken and a variety of natural disasters occurred frequently. In addition, most of the rural population lives separately in Guizhou. To achieve normal communication signal transmission, more base stations need to be built. Special natural conditions lead to a long term and an expensive investment of communication network infrastructure construction as well as difficult management, maintenance problem of high cost and low rate of return in Guizhou. This makes the construction of rural information infrastructure in Guizhou needs to spend more than the others.

\section{B. Low level of economic development is the main factor of information poverty in Guizhou}

Guizhou is facing a serious problem of poverty. 83 counties (cities, districts) in the province (88 in totals) have the poverty alleviation and development tasks, accounting 94.13\%. 56.8\% of the counties belong to key national poverty alleviation and development counties. In 2012, the province's total population is 34.84 million. 17.8 million people are under the poverty alleviation and development, accounting for 51.1\%. 9.23 million rural people in the province's are poor, rural poverty rate is $26.8 \%$. In 2012, Guizhou province's GDP was 685.22 billion yuan, ranked 26th in the country. Per capita net income of rural residents' family is 4753 yuan, which is 3163.58 yuan lower than the national average (7916.58 yuan) ${ }^{3}$. Related studies have shown that informatization development level is closely related to the level of economic development in the region, which is a significantly positive correlation. For instance, from data analysis of the information level of total index of provinces and cities and the province's per capita GDP from 1995-2001, the economic level of Guizhou is 8.35, ranks 31 ; informatization level is 32.15 , ranks 29 ; the correlation 
coefficient for information technology and economic development is 0.92735 [3]. The low economic level makes rural production and living ways relatively close, thus modern management concept hardly can be accepted. Insufficient demand for information makes insufficient resources for economic development such as people, goods and technology. The resources cannot be integrated utilized in the countryside. Information poverty restricts the rural economic development in Guizhou meanwhile the economic poverty intensifies the information poverty, which forms a vicious cycle.

\section{Limited education of farmers is the direct factor of information poverty in Guizhou}

On one hand, farmers in Guizhou have low degree of education. The proportion of primary school and junior high school accounts for the largest in relation to their education level. Second is illiterate or semiliterate, the least is the proportion of high school and technical secondary school or above (see table II). On the other hand, farmers in Guizhou have limited training opportunities. The research indicates that the main content of the training is practical skills. Around $49 \%$ of interviewees have had cultivation technique trainings. The main method of training was providing guidance and meeting the field. $13 \%$ of the interviewees had an annual training and, $12 \%$ of people participated in the training two times a year. Only $5.3 \%$ of people have participated in training more than three times per year.

\section{CONSIDERATION FOR THE INFORMATION POVERTY ALLEVIATION IN GUIZHOU}

In recent years, Guizhou province has taken some activities to alleviate the information poverty, such as: to enhance the national grid facilities, to extend the internet coverage in rural area, to build the "three- grid" interaction service system and so on.

The characteristic of Guizhou information poverty has cause three key difficulties:

First, the information knowledge level of rural residents cannot be improved shortly. Second, the rural information environment cannot be changed shortly. Thirdly, the rural information service quality cannot be improved shortly. These difficulties are the restrict factors to implement the usual information poverty alleviation methods. Therefore, to alleviate the information poverty in Guizhou should consider the following aspects:

\section{A. Change the perception, guide the information poverty alleviation by the theory of cooperative games}

Throughout China's rural information poverty countermeasures research, both governments and organizations implement active push solution. Farmers can only passive accept the situation. The enthusiasm and receptivity of farmers affect the effect of information poverty alleviation. Game theory is the study of strategic decision making. Specifically, it is "the study of mathematical models of conflict and cooperation between intelligent rational decision-makers". That is to say, the subject first addressed zero-sum games, such that one person's gains exactly equal net losses of the other participant or participants [4]. A game theorist typically uses these elements, along with a solution concept of their choosing, to deduce a set of equilibrium strategies for each player such that, when these strategies are employed, no player can profit by unilaterally deviating from their strategy. These equilibrium strategies determine equilibrium to the game - a stable state in which either one outcome occurs or a set of outcomes occurs with known probability [5]. According to the "Boxed Pig Game" ,the profit of information poverty alleviation would benefit some people much better than the others. Under this situation, those who have more benefit would be more enthusiastic than the others and those who have less or no benefit would not care about it. This suggests information poverty alleviation has to depend on those enthusiastic ones. Thus, when Guizhou is under the development of rural informatization demonstration province, fundamental point is to benefit more people by implementing information poverty alleviation.

\section{B. Enhancing the government's management and improving the investment efficiency}

The government investment projects refer to those non-profit fiscal investment construction projects of government. They include public welfare and public infrastructure construction, protection and improvement of ecological environment, less developed areas' development promotion, scientific and technological progress promotion and industrialization of high and new technology such as relationship between global key areas and weak links of the project [6]. Generally speaking, both informational and educational rural infrastructure constructions belong to government investment projects. Due to the huge amount of financial input in these projects, as well as their close relationship with the harmony of rural society and sustainable development of economy, supervision of these projects is vital. Otherwise, low efficiency of investment and low quality of projects will occur. Improving the quality of government's management is the only way to ensure the efficiency and quality of constructions of projects, in order to underline the foundation of projects and benefit the people. Zhang (2010), put forward a cooperation management model, which is on the basis of cooperation and target oriented. It provides reference of improving the government's management of investment projects.

\section{Improving the level of rural information service and providing information service to meet the rural information needs}

Providing information service to rural areas is to adapt the information needs, information acquisition and habits of the farmers. Details are as follows:

- Firstly, it is to solve the blocking problem of information sources. Under provincial coordination, the information push service is provided to farmers through integrating agriculture related information of agriculture, meteorology, health, finance, disaster prevention and mitigation, etc.

- Secondly, it is to improve the practicality of information products. Fully taking the advantage of the popularity of radio and television in rural areas, 
local agriculture information channels should be designed to play agricultural products and cultivation techniques which attract farmers.

- Thirdly, it is to build the rural information service platform. Information network should be established to meet the needs of the country and the characteristic requirements of the township. Meanwhile, agricultural colleges and other social forces should be encouraged to participate in the construction of the rural information resources to build a rural information database.

- Fourthly, it is to gradually promote the information market. Information service of providing agricultural products circulation information, agricultural skills training and agricultural information should be commercialized. Subdividing farmers' information needs, improving the business information service level and forming a healthy supply-demand relationship, will promote the circulation of industry information and the precision and sustainability of information products processing.

\section{Enhancing the information education in rural area,} increasing rural residents information knowledge degree

Rural residents play a key role in rural informatization. Their attitude is important. It is necessary to develop their inner requirements of information. It is also important to increase rural residents' ability of using information. The rural area information education should pay attention to the combination of method education and information-use skills. On one side, building an educational method system include: information education, trainer data base building and training result tracking. It is necessary to improve rural education facilities; to increase teaching resource and education subdivides. Especially apply popularize agriculture skills and internet information skills; and let famer learn how to use internet information to know the data. The trainer data base building should includes data analysis, trainers training schedule and so on. The training result tracking includes trainers' feedback, trainers' skill practice and so on. On the other side, information-use talents training could demonstrate the information-use achievement faster.

\section{CONCLUSION}

The natural condition of Guizhou not only has vital influence on its economic development, and also has influence on its information development level. The lack of information makes the increasing of city economic development cost, at the same time restricts the economic development. The usual rural information poverty alleviation ways cannot be efficiently implemented. This article base upon sufficient research analysis, discussed the effective ways to alleviate the rural information poverty. The key analysis aspects include: the characteristics of Guizhou information poverty, the poverty level and natural conditions, economic development level, education degree of rural residents and so on. After the analysis, this article gave out several methods of practicing the information poverty alleviation: to practice 'cooperative game' method, to enhance the management of government investment projects, to improve information service level in rural area and to enhance the education of information knowledge in rural area. These ways would help government take action on anti-poverty base upon Guizhou rural information poverty characteristics.

\section{ACKNOWLEDGMENT}

The research is a periodic fruit of University Humanity Society Science Research Base Project in Guizhou Province. Tang Shengqin designed the questionnaire and Wu Weibing, Zhang Jin, Cai Mei and Li Ou cooperated in collecting and sorting data and material.

\section{REFERENCES}

[1] Sun GuiZhen. Study on the Rural Information Poverty in Hebei Province [D]. Hebei: Agricultural University of Hebei, 2010.

[2] Liu Juan. Study On Internet Developmental Level in China's Provinces [D].Beijing:Beijing University of Posts and Telecommunications, 2012

[3] Guo Lijuan. The Correlation between Regional Informatization and Regional Economic Development in China [J]. Industrial \& Science Tribune. 2008. 7(6)

[4] Zhang Weiying. Game Theory and Information Economics [M]. Gezhi Press. Shanghai People's Press, 2010.04.

[5] Sun Haojie,Wang Zhengbing,Wang Yunhui. Analysis of Forming Mechanism of Farmers'Cooperative Economic Organizations Based on Game Theory [J]. Journal of Dalian University of Technology (Social Sciences). 2007. 09 (15)

[6] Zhang Tao. Research on The Cooperation Mode of Government Investment Projects [M]. China Agricultural University Press. 2010.01.

[7] Ding Jianjun,Zhao Qizhao. The Cause of Rural Information Poverty and The Countermeasures to Poverty Reduction_-In Wuling Mountain Area as An Example [J]. Library and Information Work. 2014. 01(20).

[8] Xu jinhua,Yang lei,Zhang yi. Research on the Characteristics and Path of Urbanization Development in Guizhou [C]. The Reform of Urban and Rural Governance and Planning_-2014 Annual Meeting of Chinese Urban Planning (13 Regional Planning and Urban Economy) 2014.09.

[9] Kong Fantao. Developing Agricultural Informatics [J]. Guangdong Agricultural Sciences, 2012. 15:219-223.

[10] Mahfuz Ashraf,BushraTahseen Malik.Gonokendra model: a response to "information poverty" in rural areas of Bangladesh[J].information Technology for Development, 2011, Vol.17 (2):153-161

[11] Simone cecchini,chfistopher scott.Can information and communications technology applications contribute to poverty reduction[J].Lessons from rural India.Information Technology for Development,2003,10(2):73-84

[12] Gregory W. Lawrence.Information Poor, Information Rich: Rural Ameri ca and the Internet[J].Journal of Agricultural \& Food Information, 1994,2 (3):71-81 